\title{
Evaluation of the attitudes towards the use of drugs in an urban Northeastern population of Brazil
}

\author{
Avaliação das atitudes de uma população urbana do nordeste do Brasil com relação ao uso de \\ fármacos
}

Laís Lima de Oliveira1, Gêniton Santos Lima², Nathale Prates Ribeiro Moura1, Rosiane Santana Andrade Lima ${ }^{3}$, Paulo Ricardo Saquete Martins-Filho' ${ }^{1}$, Diego Moura Tanajura ${ }^{1}$

DOI 10.5935/1806-0013.20160004

\section{ABSTRACT}

BACKGROUND AND OBJECTIVES: The use of drugs has improved general population quality of life and health conditions. However, pharmaceutical industries spread a purely curative view and total well-being associated to its use. This study aimed at evaluating population attitudes with regard to the use of drugs in the city of Frei Paulo/SE, Brazil.

METHODS: Data were collected by means of a questionnaire applied by trained people and in the presence of the community health agent, in the micro-regions of the Family Health Strategy.

RESULTS: Participated in the study 186 people, predominantly females $(77.95 \%)$ with mean age of $45.25 \pm 14.91$ years. $73.12 \%$ of respondents have reported reading patient information leaflets, however approximately $40.0 \%$ of respondents have not completed elementary school, which might have impaired the understanding of such information. 31.72\% have stated knowing that drugs in high doses may harm health. However, $9.14 \%$ of participants have confirmed using drugs in doses higher than those prescribed, and from them, 29.41\% had complications.

CONCLUSION: It is imperative the development of public policies focusing on population information and awareness with regard to the responsible use of drugs.

Keywords: Attitudes, Drugs, Headache.

\footnotetext{
1. Universidade Federal de Sergipe, Hospital Universitário, Laboratório de Patologia Investigativa, Aracaju, SE, Brasil.

2. Secretaria Municipal de Saúde, Frei Paulo, SE, Brasil.

3. Universidade Federal de Sergipe, Departamento de Medicina, Lagarto, SE, Brasil.

Submitted in August 6, 2015.

Accepted for publication in November 18, 2015

Conflict of interests: None - Sponsoring sources: None.

Corresponde to:

Diego Moura Tanajura

Rua Cláudio Batista, s/n - Bairro Sanatório

49060-100 Aracaju, SE, Brasil.

E-mail: diegomouratanajura@gmail.com

(C) Sociedade Brasileira para o Estudo da Dor
}

\section{RESUMO}

JUSTIFICATIVA E OBJETIVOS: A utilização de fármacos tem aumentado a qualidade de vida e as condiçóes de saúde da população em geral. Entretanto, as indústrias farmacêuticas propagandeiam uma visão puramente curativista e de pleno bem-estar associado ao seu uso. O objetivo deste estudo foi avaliar as atitudes da população frente ao uso de fármacos no município de Frei Paulo/SE, Brasil.

METODOS: Os dados foram coletados por meio da aplicação de um questionário por pessoas treinadas e na presença do agente comunitário de saúde, nas microrregióes da Estratégia de Saúde da Família.

RESULTADOS: Foram entrevistadas 186 pessoas, com predominância do gênero feminino $(77,95 \%)$ com média de idade de $45,25 \pm 14,91$ anos. $73,12 \%$ da populaçáo relataram praticar a leitura da bula, todavia, aproximadamente $40,0 \%$ da população não completaram o primeiro grau, o que pode ter prejudicado a compreensão das informaçóes presentes nela. 31,72\% afirmaram conhecer que os fármacos, em doses elevadas, podem causar lesôes à saúde. Entretanto, 9,14\% dos participantes confirmaram a utilização de fármacos em dose maiores do que as prescritas e, destes, 29,41\% apresentaram complicaçóes.

CONCLUSÃO: Dessa forma, é imperativo o desenvolvimento de políticas públicas com foco na informação e conscientização da população quanto ao uso responsável de fármacos.

Descritores: Atitudes, Cefaleia, Fármacos.

\section{INTRODUCTION}

The use of drugs has improved quality of life (QL) and health condition of the general population ${ }^{1}$. However, in search for new market achievements, pharmaceutical industries spread a purely curative and welfare-related vision associated to the use of drugs. This context targets the misuse of certain drugs, with consequent increase in the onset of side effects, thus increasing expenditure of public money. In an attempt to rationalize the use of drugs, governmental initiatives have been launched aiming at controlling the sale of drugs ${ }^{2,3}$. The pharmacist is the professional in charge of the whole process of dispensing drugs, which comprises from a detailed analysis of the prescription to providing information necessary for the therapy to be carried out ${ }^{4}$. However, researches have shown that the clerk is the most frequently present professional in the direct orientations to the user whenever the dispensation occurs ${ }^{5,6}$. In Brazil, 35\% of 
drugstores do not have the full-time presence of the pharmacist ${ }^{7}$. That situation, associated to advice from clerks, may distort the adequate process of drug dispensation and patient orientation, since these professionals are not skilled to play such role.

The aim of the study was to evaluate the attitudes of the population towards the use of drugs in the city of Frei Paulo, Sergipe, Brazil.

\section{METHODS}

This is a transversal study part of the research project on the use of drugs, "Self-drugs practices: an approach to the behavior of patients and the main risks", conducted from September 2013 to January 2014 in Frei Paulo/SE, a city with 13,974 inhabitants located 64 km away from the capital Aracaju. The research universe was the 8,213 inhabitants that live in the urban area of the city. Sample size was calculated taking into account 5\% sampling error, 95\% confidence interval and estimated prevalence of self-drugs of $90 \%$, adding up to a minimal sample of 137 subjects. People aged between 18 and 80 years agreed to participate in the study by signing the free and informed consent term (FICT). Data were collected with questionnaires applied by trained people and in the presence of the community health agent.

The study comprised 13 micro-regions $(76.47 \%$ of the urban micro-regions). In each region, the questionnaire was applied in the first and in the seven subsequent houses, always following the constant of three, totaling 216 houses.

Participants were asked about reading of patient information leaflets, about asking clerks for help and the use of drugs in doses different from those prescribed; they were also asked about their view on whether the use of drugs could harm health.

\section{Statistical analysis}

Collected data were accounted in double entry and tabulated on the Excel ${ }^{\mathrm{TM}}$ software for the identification and correction of typographical errors, which were organized in proportions. Fisher's test was employed to evaluate differences between groups. Bioestat $5.3^{\mathrm{TM}}$ software was used for data analysis, considering statistically significant $\mathrm{p}<0.05$.

The study was approved by the Ethics Committee of the University Hospital of Aracaju/Federal University of Sergipe (CAEE $\mathrm{n}^{\circ}$ 13832613.4.0000.5546).

\section{RESULTS}

Among all houses visited ( $\mathrm{n}=216), 30$ were excluded because residents did not agree to participate in the study. Thus, 186 residents were interviewed, and 145 of them $(77.96 \%)$ were women. The average age of participants was $45.25 \pm 14.91$ years, and around $40 \%$ of the population did not complete the elementary school. In the evaluation of attitudes of the population towards the use of drugs, it was found that $73.12 \%$ read patient information leaflets before taking the drugs, $92.47 \%$ always asked the clerk for information on the drugs purchased and $43.01 \%$ stated that drugs always harms health (Table 1).

Around $14 \%$ of those interviewed reported having used the drugs in doses different from the ones prescribed by the health professional;
9.14\% used higher doses and 4.84\% used lower doses (Table 2). It was observed that $29.41 \%$ of people who made use of the drugs in higher doses suffered some kind of complication, whereas only $7.10 \%$ of those who used the same or lower doses suffered complications $(\mathrm{p}=0.0109)$ (Table 3).

Table 1. Attitudes of the population regarding the use of drugs. Frei Paulo/SE, Brazil, 2013-14

\begin{tabular}{lc}
\hline Variables & $\%$ \\
\hline Read patient information leaflets & 73.12 \\
Yes & 26.88 \\
No & \\
Ask information to clerk about the drugs purchased & 92.47 \\
$\quad$ Yes & 7.53 \\
No & \\
Drugs can harm health & 43.01 \\
Yes, always & 31.72 \\
Yes, only high dose & 16.13 \\
Sometimes & 9.14 \\
No & \\
\hline
\end{tabular}

Table 2. Use of drugs in doses different from those prescribed. Fre Paulo/SE, Brazil, 2013-14

\begin{tabular}{lc}
\hline Use drugs in doses different from those prescribed & $\%$ \\
\hline Yes, higher dose & 9.14 \\
Yes, lower dose & 4.84 \\
No & 85.48 \\
Do not know & 0.54 \\
\hline
\end{tabular}

Table 3. Association between use of medicines in higher doses and complications. Frei Paulo/SE, Brazil, 2013-14

\begin{tabular}{lccc}
\hline & $\begin{array}{c}\text { Complication - Yes } \\
\mathrm{n} \%\end{array}$ & $\begin{array}{c}\text { Complication - No } \\
\mathrm{n} \%\end{array}$ & $\mathrm{p}$ value \\
\hline Dose & & & \\
$\quad$ Higher & $5(29.41)$ & $12(70.59)$ & 0.0109 \\
$\quad$ Equal or lower & $12(7.10)$ & $157(92.90)$ & \\
\hline
\end{tabular}

\section{DISCUSSION}

Patient information leaflets, which are mandatory in drugs, could be an important ally against the inadequate use of drugs. According to the resolution of the Collegiate Board of Directors - RDC No 47/2009, information contained in patient information leaflets must follow the question-and-answer format, with a simple and complete language ${ }^{8}$. However, as it has been shown by a study performed by Sousa, Garcia and Gonçalves Junior ${ }^{9}$, patient information leaflets have a language that is hard to understand ${ }^{9}$. In the present study, $73.12 \%$ of those interviewed read patient information leaflets. Nonetheless, around $40 \%$ of the evaluated population are either illiterate or did not complete elementary education. This way, the low schooling associated to a sophisticated language contained in the leaflets may lead to wrong interpretations.

In the analyzed population $92.47 \%$ stated asking clerks for help about the drugs purchased, what can pose a risk to patient's health due to the fact that this professional does not have enough scientific and technical knowledge to take on such responsibility. This consultation with the clerk probably stems from the lack of a professional pharmacist, since it has been observed that $97 \%$ of the drugstores in the state of Sergipe do not rely on full-time pharmacists. This 
professional, who is technically responsible for the drugstore, has an important role in ensuring the correct and rational use of drugs ${ }^{10}$. In the context of the rational use of drugs, it is of high priority that information and guidance on physical characteristics, posology, conservation and application be well explained during the medical visit and in the final dispensation of the drug. However, studies have demonstrated that the knowledge on the drugs being used was considered, most of the times, as insufficient for its correct use to be ensured $^{11,12}$. That situation can also exist in the population studied because $14 \%$ of those interviewed stated having modified its therapeutics. Besides, that required medical prescription does not prevent the incorrect use of drugs. As it has been described by Mastroianni et al. ${ }^{13}, 47.7 \%$ of individuals that handed the medical prescription did not use the drugs according to the prescription and $34.09 \%$ modified the doses recommended ${ }^{13}$.

Modifications of the doses made by patients increase the risk of the onset of complications. It was observed that $29.41 \%$ of users who increased the dose suffered some kind of complication such as allergic reactions, alteration in blood pressure and headache. These complications, such as headache, can lead to self-medication ${ }^{14}$. In the case of sub-doses or doses equal to the ones prescribed, $7.10 \%$ of patients suffered complications. In this group, major complaint was therapeutic inefficacy. One of the aspects of underdosing is practiced with antibiotics, since the use of these drugs in doses below that recommended, or even their interruption, may cause therapeutic resistance $^{15}$.

\section{CONCLUSION}

The present study highlights gaps in the knowledge of the studied population concerning the use of drugs. That becomes evident when it is considered that $31.72 \%$ of interviewed individuals reported they believed that drugs only harms health in high doses, and also that $14 \%$ have ever changed the therapeutic routine prescribed. In light of all that, the development of public policies targeting the information and awareness of this population is necessary, concerning the responsible use of drugs. Besides, the presence of the full-time pharmacist in the drugstores must be motivated.

\section{ACKNOWLEDGEMENTS}

The authors would like to thank Camila Lima de Oliveira, secretary of the health office of the city of Frei Paulo/SE, and the community health agents of the city who helped with the research development. Also, we would like to thank the UFS (PIBIX/PROEX) for the scholarship to Laís Lima de Oliveira.

\section{REFERENCES}

1. Leite SN, Vieira M, Veber AP. [Drug utilization studies: a synthesis of articles published in Brazil and Latin America]. Cien Saude Colet. 2008;13(Suppl):793-802. Portuguese.

2. Araújo CP, Bochner R, Nascimento AC. Legal frameworks of drug advertisement: progress and setbacks. Physis. 2012; 22(1):331-46.

3. Portela AS, Leal AA, Werner RP, Simóes MO, Medeiros AC. Políticas públicas de medicamentos: trajetória e desafios. Rev Ciênc Farm Básica Apl. 2010;31(1):9-14.

4. Conselho Federal de Farmácia (Brasil). Resolução n 357, de 20 de abril de 2001. Boas práticas em farmácia. Diário Oficial da Uniấo 27 abr 2001; Seçấo 1.

5. Arrais PS, Barreto ML, Coelho HL. [Drug prescription and dispensing from the patient's perspective: a community-based study in Fortaleza, Ceara State, Brazil]. Cad Saude Publica. 2007;23(4):927-37. Portuguese.

6. Alencar TO, Bastos VP, Alencar BR, Freitas IV. Dispensação farmacêutica: uma análise dos conceitos legais em relaçấo à prática legal. Rev Ciênc Farm Básica Apl. 2011;32(1):89-94

7. Ensp/Fiocruz. $35 \%$ das farmácias sem farmacêutico em tempo integral | Radis - comunicação em saúde. Available at: http://www6.ensp.fiocruz.br/radis/conteudo/35-das-farmacias-sem-farmaceutico-em-tempo-integral. Accessed June 9, 2015.

8. Agência Nacional de Vigilância Sanitária (Brasil). Regras para elaboração, harmonizaçấo, atualizaçấo, publicaçáo e disponibilização de bulas de medicamentos para pacientes e para profissionais de saúde. Resolução RDC No 47, de 8 de setembro de 2009. Diário Oficial da União 9 set 2009; Seçẫo 1.

9. Sousa JP, Garcia JL, Gonçalves Junior AF. O paciente e a bula e suas maiores dificuldades. Rev Fac Montes Belos. 2014;7(2):10-22.

10. Kishi MA, Menegasso PE, Rizzi RC, Polacow M. Medicamentos isentos de prescrição. $1^{\text {a }}$ ed. Brasília, 2010. Available at: http://portal.crfsp.org.br/phocadownload/fasciculo_ii_internet.pdf. Accessed June 11, 2015.

11. Oenning D, Oliveira BV, Blatt CR. [Patient awareness about drugs prescribed after medical appointment and prescription]. Cien Saude Colet. 2011;16(7):3277-83. Portuguese.

12. Portela Ada S, Simões MO, Fook SM, Montenegro Neto AN, da Silva PC. [Medica prescriptions: adequate orientation to medicine use?] Cien Saude Colet. 2010;15(Suppl 3):3523-8. Portuguese.

13. Mastroianni Pde C, Lucchetta RC, Serra Jdos R, Galduróz JC. [Household storage and use of medications in a population served by the family health strategy in Brazil]. Rev Panam Salud Publica. 2011;29(5):358-64. Portuguese.

14. Oliveira AL, Pelógia NC. Headache as main self medication among health care professionals. Rev Dor. 2011;12(2):99-103.

15. de Aquino DS. [Why rational drug use must be a priority?] Cien Saude Colet. 2008;13(Suppl):733-6. Portuguese. 